\title{
Inhaltsverzeichnis :
}

I. Zündung und Verbrennungsmotor

1. Geschichtliches . . . . . . . . . . . . . . . . . 1

2. Zündzeitpunkt . . . . . . . . . . . . . . . . . 12

3. Zündleistung $\ldots \ldots \ldots 21$

\section{Theorie der Zündung}

1. Erzeugung der Hochspannung . . . . . . . . . 30

2. Erzeugung des Primärstromes . . . . . . . . . 45

3. Vergleich von Magnet- und Batteriezündung ... . 76

III. Wesentliche Konstruktionsteile des Zünders

1. Magnetischer Kreis . . . . . . . . . . . . . 83

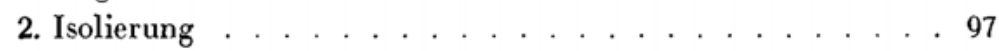

3. Unterbrecher und Kondensator . . . . . . . . . 107

IV. Verschiedene Zünderbauarten

1. Magnetzünder . . . . . . . . . . . . . 130

2. Batteriezünder . . . . . . . . . . . . . . . 159

3. Kombinierte Maschinen . . . . . . . . . . . . 181

V. Einbau, Störungen und Hilfseinrichtungen des Zünders

1. Einbau . . . . . . . . . . . . . . . . . . 201

2. Störungen . . . . . . . . . . . . . . . . . . . . 218

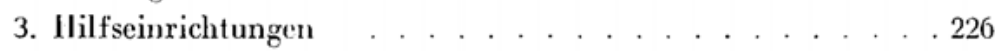

\section{Zündkerzen}

1. Beanspruchung und Arbeitsbedingungen . . . . . 250

2. Konstruktionsteile . . . . . . . . . . . . . . . . 263

3. Einbau und Wartung . . . . . . . . . . . 275 